\title{
Talaromycosis Marneffei pada Pasien HIV
}

Aulia Ihsani ${ }^{1}$, Raveinal ${ }^{2}$

\begin{abstract}
Abstrak
Talaromycosis marneffei adalah infeksi jamur yang disebabkan Talaromyces marneffei. Talaromikosis adalah salah satu infeksi oportunistik yang sering mengenai orang dengan infeksi Human Immunodeficiency Virus (HIV) stadium akhir di Asia Tenggara, India timur laut, Cina Selatan, Hongkong, dan Taiwan. Gejala klinis talaromikosis tidak spesifik, seperti demam, anemia, penurunan berat badan, hepatomegali, splenomegali, gangguan pernapasan dan manifestasi kulit. Diagnosis ditegakkan berdasarkan kecurigaan klinis dengan konfirmasi pemeriksaan histopatologi. Dilaporkan pasien laki-laki berusia 29 tahun, dirawat di Bagian Penyakit Dalam RSUP Dr. M. Djamil Padang, dengan keluhan utama muncul bintil-bintil berwarna kehitaman hampir diseluruh wajah sejak 3 bulan yang lalu. Pasien sudah dikenal menderita HIV sejak 4 bulan yang lalu dan sudah mendapat terapi antiretroviral (ARV). Didapatkan plak hiperpigmentasi pada wajah dan hepatomegali. Laboratorium didapatkan kadar hemoglobin 8,9 gr/dl, CD4 8 sel/uL dan pemeriksaan histopatologi yang menunjukkan massa sporis eosinofilik di intraseluler dan diantara stroma jaringan ikat. Pemberian ARV dilanjutkan dan juga diberikan antijamur.
\end{abstract}

Kata kunci: human immunodeficiency virus, talaromycosis, talaromyces marneffei

\section{Abstract}

Talaromycosis marneffei is a mycotic disease caused by Talaromyces marneffei. Talaromycosis is one of the most common opportunistic infections in a patient with the advanced stage of Human Immunodeficiency Virus (HIV) in Southeast Asia, northeast India, South China, Hong Kong and Taiwan. Clinical manifestations of talaromycosis are not specific, include fever, anemia, weight loss, hepatomegaly, splenomegaly, respiratory distress and cutaneous manifestations. Diagnosis is based on clinical suspicion and confirmed by histopathological examination. It has been reported a 29-years-old male patient treated in the Internal Medicine Dr. M. Djamil Padang Hospital with chief complaints is a blackish nodule on almost the entire face since 3 months ago. The patient has been known to suffer from HIV since 4 months ago and has got antiretroviral therapy (ARV) hyperpigmented plaque on the face and hepatomegaly. Laboratories obtained hemoglobin levels of 8,9 gr/dl, CD4 $8 \mathrm{cells} / \mathrm{ul}$, and histopathological examination showed eosinophilic spherical mass in intracellular and between connective tissue stroma. In addition to continued $A R V$ therapy, the patient are also given antifungal.

Keywords: human immunodeficiency virus, talaromycosis, talaromyces marneffei

Affiliasi penulis: 1. Program Studi Pendidikan Dokter Spesialis- IImu Penyakit Dalam, Fakultas Kedokteran, Universitas Andalas, Padang, Indonesia. 2. Bagian IImu Penyakit Dalam, Fakultas Kedokteran, Universitas Andalas/RSUP Dr. M. Djamil Padang, Indoensia

Korespondensi: Aulia Ihsani, Email: drauliaihsani@hotmail.com Telp: 081372960689

\section{PENDAHULUAN}

Talaromyces marneffei (sebelumnya Penicillium marneffei) merupakan jamur dimorfik yang menyebabkan infeksi jamur yang disebut talaromikosis (penisiliosis) marneffei. Talaromikosis merupakan infeksi oportunistik terkait HIV yang paling penting di Asia Tenggara dan Asia Selatan dan menempati peringkat ketiga setelah tuberkulosis dan meningitis kriptokokus. ${ }^{1}$ Insiden talaromikosis di Vietnam, sebesar $4,4 \%$ dan sebanding dengan kejadian AIDS pada tahun $2004-2009 .^{2}$ Satu laporan kasus pasien HIV asal Belanda yang didiagnosis sebagai talaromikosis marneffei setelah berkunjung ke Sumatera, Indonesia. ${ }^{3}$ Dua kasus lain juga dilaporkan, dimana satu kasus pasien HIV yang memiliki riwayat berkunjung ke beberapa negara Asia Tenggara, 
termasuk Indonesia, dan satu kasus warga Tiongkok penerima transplan ginjal yang tinggal di Indonesia. ${ }^{4}$ Belum ada kasus talaromikosis marneffei yang didiagnosis di Indonesia. ${ }^{5}$

HIV merupakan faktor risiko utama talaromikosis di daerah endemik. Jamur merupakan penyebab utama dari infeksi oporunistik yang terkait HIV pada daerah-daerah ini, menyebabkan peningkatan angka rawatan yang terkait AIDS sebesar 16\%, dan merupakan penyebab utama kematian dan infeksi darah terkait HIV di Vietnam dan Cina Selatan. Talaromikosis terjadi pada pasien HIV stadium lanjut dengan hitung limfosit T CD4 $<100 \mathrm{sel} / \mathrm{mm}^{3}$. Insiden talaromikosis semakin meningkat pada pasien dengan imunodefisiensi yang kembali dari perjalanan atau imigran dari daerah endemik dan daerah lain yang telah dilaporkan, seperti Jepang, Australia, Belgia, Perancis, Jerman, Belanda, Swedia, Swiss, Inggris, Oman dan Amerika Serikat, serta pada pasien dengan keadaan imunodefisiensi primer (seperti pada limfopenia CD4 idiopatik, akibat mutasi CYBB, CD40L, atau mutasi STAT1/STAT3 pathway) dan sekunder (seperti pasien dengan penyakit autoimun yang mendapat terapi kortikosteroid dan/atau imunosupresif, keganasan padat dan hematologi, transplantasi organ padat). ${ }^{6}$

Sebagian besar pasien yang terinfeksi jamur ini awalnya menunjukkan gejala konstitusi, seperti demam, penurunan berat badan dan malaise. Manifestasi kulit terlihat pada $>70 \%$ kasus dan merupakan petunjuk terbaik untuk diagnosis. Lesi berupa sebagai papul di wajah, dada, dan ekstremitas. Bagian tengah papul kemudian menjadi nekrotik, sehingga tampak seperti papula umbilicated. Infeksi jamur ini juga menunjukkan tanda dan gejala yang melibatkan sistem retikuloendotelial, seperti anemia, hepatosplenomegali, dan limfadenopati. Sistem respirasi juga sering terlibat dengan gejala batuk produktif, dispnea dan hemoptisis. Rontgen thorak menunjukkan infiltrat retikular difus. Karena talaromikosis biasanya mengenai pasien dengan HIV stadium lanjut, 55 - $77 \%$ kasus mengalami infeksi oportunistik lainnya secara bersamaan. ${ }^{7}$

Sumber penularan Talaromycosis marneffei saat ini masih menjadi perdebatan apakah bersifat zoonotik atau sapronotik. Talaromyces marneffei awalnya dicurigai sebagai penyakit transmisi zoonotik yang ditularkan melalui hewan. Penelitian epidemiologi molekuler menemukan persamaan tipe mikrosatelit antara pasien yang menderita talaromikosis dengan isolat yang berasal dari tikus bambu pada daerah yang sama. Kecurigaan terhadap transmisi sapronotik Talaromyces marneffei juga tampak dalam beberapa penelitian epidemiologi. Chariyalertsak et al. menemukan risiko infeksi Talaromyces marneffei lebih tinggi pada pasien dengan pekerjaan yang sering terpapar tanah, sedangkan paparan dan konsumsi tikus bambu tidak menjadi risiko infeksi. Dicurigai tikus bambu memang hanya reservoar alami Talaromyces marneffei. ${ }^{8}$

Diagnosis talaromikosis ditegakkan bila didapatkan pertumbuhan fungi dari spesimen jaringan biopsi atau darah. Diagnosis presumtif dapat ditegakkan dengan cepat melalui pemeriksaan histopatologi pada lesi kulit atau materi biopsi lain. Pemeriksaan mikroskopis dengan pewarnaan Wright pada spesimen biopsi menunjukkan banyak sel ragi basofilik bulat, oval dan elips intraseluler dan ekstraseluler. 7,9

Infeksi talaromikosis yang tidak diterapi dengan adekuat menyebabkan mortalitas mencapai 100\%. Obat pilihan untuk talaromikosis ini adalah liposomal amphotericin B 3 - $6 \mathrm{mg} / \mathrm{kgBB} / \mathrm{hari}$, IV, selama 2 minggu, dilanjutkan dengan itraconazole 400 mg/hari, $\mathrm{PO}$, selama 10 minggu. Alternatif lainnya, voriconazole $6 \mathrm{mg} / \mathrm{kgBB} / 12$ jam, IV, pada hari I, kemudian 4 $\mathrm{mg} / \mathrm{kgBB} / 12$ jam, IV, minimal selama 3 hari, dan dilanjutkan dengan voriconazole $200 \mathrm{mg} 2$ kali sehari, $\mathrm{PO}$, maksimal selama 12 minggu. Infeksi ringan dapat diberikan itraconazole oral $400 \mathrm{mg} /$ hari selama 8 minggu. $^{10}$

\section{KASUS}

Seorang pasien laki-laki berusia 29 tahun, dirawat di Bagian Penyakit Dalam RSUP Dr. M. Djamil Padang dengan keluhan utama muncul bintil-bintil berwarna kehitaman di seluruh wajah sejak 3 bulan yang lalu. Awalnya bintil tersebut berbentuk bintik kemerahan di pipi kiri, teraba keras, tidak berair, tidak gatal dan tidak nyeri. Kemudian bintik kemerahan menjadi bertambah besar dan kehitaman serta tampak bersisik. Pasien juga mengeluh bercak putih disekitar 
mulut, lemah letih dan penurunan berat badan serta benjolan di sekitar anus. Pasien sudah dikenal menderita HIV sejak 4 bulan yang lalu dan telah mendapat terapi ARV (tenofovir $1 \times 300 \mathrm{mg}$, efavirenz 1x600mg, dan lamivudine 1x300 mg). Pasien memiliki riwayat perilaku seks sesama jenis dan riwayat hubungan seksual dengan PSK. Tidak ada riwayat travelling ke luar negeri.

Pemeriksaan fisik didapatkan keadaan umum sakit sedang dan tanda vital dalam batas normal. Lingkar lengan atas $16 \mathrm{~cm}$ dan Indeks massa tubuh $13,6 \mathrm{~kg} / \mathrm{m}^{2}$. Pada kulit didapatkan papul hiperpigmentasi pada wajah, leher depan, leher belakang dan lengan bawah kanan. Terdapat oral thrust pada mulut. Pemeriksaan abdomen didapatkan hepatomegali, namun lien tidak teraba. Pada anus tampak adanya vegetasi perianal.

Pada pemeriksaan laboratorium didapatkan hemoglobin $8,9 \mathrm{gr} / \mathrm{dl}$, leukosit $1480 / \mathrm{mm}^{3}$, hematokrit $27 \%$, trombosit $173.000 / \mathrm{mm}^{3}$, albumin $2,2 \mathrm{gr} / \mathrm{dl}$, globulin 3,4 gr/dl, natrium $121 \mathrm{mmol} / \mathrm{dl}$, kalium 2,5 $\mathrm{mmol} / \mathrm{dl}$, klorida $96 \mathrm{mmol} / \mathrm{dl}$, ureum $13 \mathrm{mg} / \mathrm{dl}$, kreatinin 0,3 $\mathrm{mg} / \mathrm{dl}$ dan CD4 $8 \mathrm{sel} / \mu \mathrm{l}$. Rontgen thorak tidak ditemukan kelainan. Pemeriksaan acetowhite positif. Pemeriksaan VDRL dan TPHA non reaktif. Pada pemeriksaan biopsi kulit didapatkan gambaran massa spheris eosinofilik yang sebagian berada intraseluler dan sebagian di antara stroma jaringan ikat yang sesuai dengan talaromikosis. Pasien didiagnosis dengan talaromikosis, HIV stadium klinis IV dengan wasting syndrome, dan kondiloma akuminata.

Pasien ini diterapi dengan flukonazole $200 \mathrm{mg} / \mathrm{hari}$, IV, selama 5 hari, kotrimoxazole 960mg/hari, isoniazid 300mg/hari dan pemberian ARV dilanjutkan. Pasien juga diberikan edukasi untuk memperbaiki gaya hidup dan meningkatkan kepatuhan minum obat. Setelah 5 hari, tidak tampak penambahan lesi. Kemudian, pasien dipulangkan dan diberikan flukonazole $150 \mathrm{mg}$, PO, selama 10 minggu. Pasien dianjurkan kontrol ke poli penyakit dalam setiap 4 minggu untuk follow up pengobatan.

\section{PEMBAHASAN}

Manifestasi klinik yang tidak khas menyebabkan besarnya kemungkinan terjadi kesalahan diagnosis ataupun tidak terdiagnosis. ${ }^{11}$ Talaromikosis adalah infeksi diseminata yang disebabkan oleh Talaromyces (Penicillium) marneffei. Infeksi Talaromyces marneffei merupakan penyakit endemik pada pasien dengan imunodefisiensi sel $\mathrm{T}$ di Asia Tenggara, terutama Thailand utara, Vietnam dan Cina Selatan. Berdasarkan anamnesis, kita belum dapat menegakkan diagnosis talaromikosis pada pasien ini karena talaromikosis sendiri umumnya memiliki manifestasi klinik yang tidak spesifik. Demam, anemia dan penurunan berat badan merupakan manifestasi klinik yang paling sering ditemukan. Pasien dapat memiliki lesi kulit dengan berbagai gambaran seperti abses subkutan, ulkus dan papul menyerupai moluscum contagiosum. ${ }^{12}$

Berdasarkan anamnesis, pasien ini mengeluhkan adanya bintil berwarna kehitaman pada hampir seluruh wajah (Gambar 1) yang disertai lemah letih dan penurunan berat badan. Pada pemeriksaan fisik, didapatkan hepatomegali, namun tidak ada splenomegali. Sedangkan, menurut literatur, demam dan splenomegali lebih banyak terjadi pada pasien dengan HIV. ${ }^{10}$ Namun, pada pasien ini, kedua hal tersebut tidak ditemukan. Hal ini menyebabkan kami memikirkan diagnosis lain pada pasien ini, yaitu histoplasmosis, dengan diagnosis banding sarkoma kaposi dan sifilis, dimana penyakit ini juga sering ditemui pada pasien HIV. Oleh karena kesulitan memastikan diagnosis hanya berdasarkan gejala klinis inilah yang mengharuskan kecurigaan talaromikosis dipastikan dengan pemeriksaan laboratorium. ${ }^{5}$

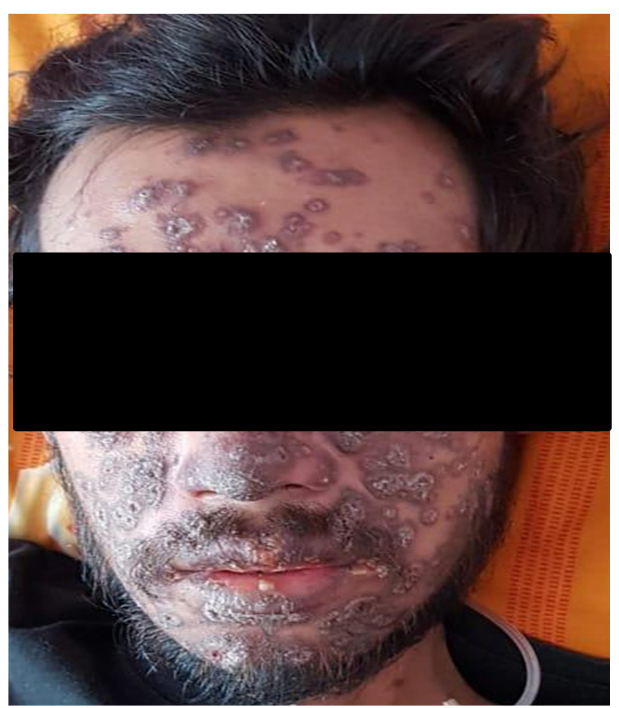

Gambar 1. Manifestasi kulit pada talaromikosis 
Penentuan riwayat perjalanan ke daerah endemik merupakan hal yang penting untuk dapat mendiagnosis Talaromikosis dengan cepat. ${ }^{13}$ Pada kasus ini, pasien menyangkal telah melakukan perjalanan ke luar negeri, terutama negara Asia Tenggara, dan negara endemik lainnya serta melakukan kontak dengan orang dari negara-negara tersebut. Pasien termasuk masyarakat dengan sosial ekonomi menengah ke bawah yang sehari-hari hanya berjualan di pasar.

Pemeriksaan darah didapatkan hemoglobin 8,9 $\mathrm{gr} / \mathrm{dl}$, leukosit $1480 / \mathrm{mm}^{3}$ dan CD4 $8 \mathrm{sel} / \mu \mathrm{l}$. Talaromikosis pada pasien HIV lebih sering terjadi pada pasien dengan leukopenia dibandingkan pasien non-HIV. ${ }^{10}$ Studi oleh Syaziah et al (2018) melaporkan bahwa dari 419 pasien HIV dengan talaromikosis didapatkan 82,9\% dengan CD4 dibawah $50 \mathrm{sel} / \mu \mathrm{l}$ dengan median CD4 $16 \mathrm{sel} / \mu \mathrm{l}{ }^{1}$

Pada kasus ini, dilihat dari jenis kelamin dan usia pasien termasuk pada kelompok yang beresiko menderita talaromikosis. Menurut Kawila et al (2013), $70-80 \%$ kasus talaromikosis dialami oleh laki-laki. ${ }^{14}$ Beberapa studi sebelumnya yang dilakukan Kawila et al (2013) dan Le et al (2011) di Thailand bagian utara dan Vietnam menunjukkan kasus talaromikosis pada pasien HIV terjadi pada usia muda (antara 28 - 48,5 tahun) dibandingkan pada pasien tanpa HIV (antara 50 - 64 tahun). ${ }^{14,15}$

\section{Pemeriksaan laboratorium Talaromyces} marneffei meliputi pemeriksaan langsung, termasuk pemeriksaan histopatologi, kultur dan serologi. Pemeriksaan histopatologi dan kultur merupakan pemeriksaan yang paling sering dilakukan untuk deteksi jamur. Pemeriksaan histopatologi dapat mendeteksi jamur dari berbagai spesimen. Jamur tampak sebagai fission arthroconidia, sel bulat sampai oval yang dapat membelah dengan penampakan cross wall formation di dalam makrofag atau histiosit. Kultur dilakukan sebagai konfirmasi pemeriksaan histopatologi. ${ }^{16}$ Pasien HIV dengan talaromikosis memliki kadar antibodi yang lebih rendah dengan antigen Talaromyces marneffei yang lebih tinggi jika dibandingkan dengan pasien non HIV. ${ }^{17}$ Pemeriksaan galactomannan untuk aspergilosis diketahui dapat digunakan untuk mendeteksi galactomannan pada talaromikosis sehingga dapat membantu dalam menegakkan diagnosis talaromikosis. ${ }^{18}$ Pada kasus ini, dari pemeriksaan histopatologi tampak beberapa kelompokan granuloma yang terdiri dari histiosit, limfoma, debris necrotic, dan tampak massa spheris eosinofilik yang sebagian berada intraseluler dan sebagian di antara stroma jaringan ikat, yang sesuai dengan gambaran jamur talaromyces (Gambar 2, lingkaran merah). Karena keterbatasan sarana, serologi dan kultur jamur tidak bisa kami lakukan.

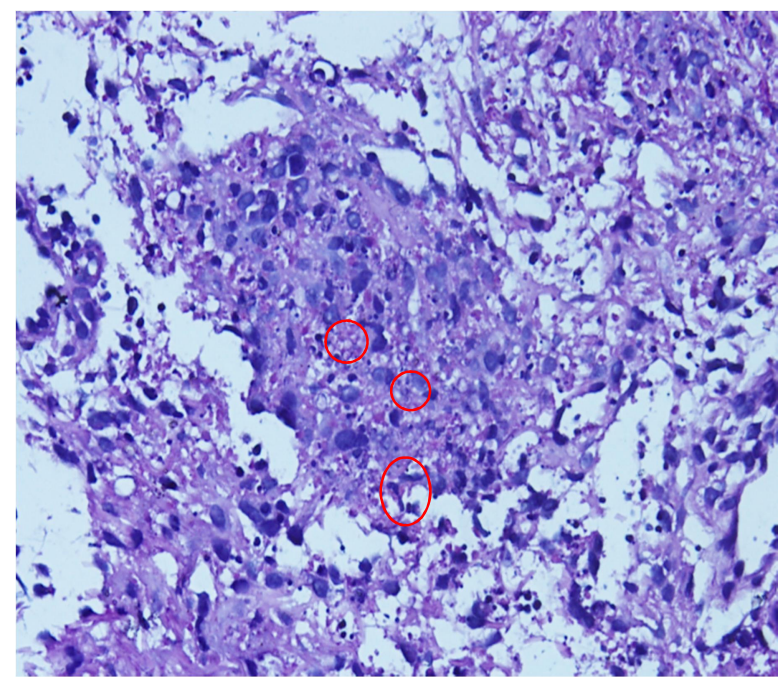

Gambar 2. Gambaran histopatologi Talaromyces

Pasien diberikan terapi fluconazole 1x200 mg, IV. Menurut literatur, talaromikosis menunjukkan respon baik dengan pemberian antifungi dari golongan 5flucytosine dan azole, termasuk miconazole, ketokonazole dan itraconazole. Secara in vitro, fluconazole kurang aktif dibandingkan golongan azole lainnya. Respon terapi paling baik ditunjukkan dengan pemberian itraconazole dan buruk dengan fluconazole. Dan amphotericin B secara klinis juga efektif dalam mengatasi talaromikosis, walaupun secara in vitro menunjukkan hasil yang bervariasi. ${ }^{18}$ Namun begitu, alasan kami tetap memberikan fluconazole pada kasus ini disebabkan karena sistem jaminan kesehatan yang berlaku saat ini hanya menanggung fluconazole. 


\section{SIMPULAN}

Rendahnya CD4 menjadi penyebab pasien HIV ini beresiko tertular talaromikosis.

\section{DAFTAR PUSTAKA}

1. Syaziah I, Azura SS, Tzar MN. Epidemiological and clinical features of talaromycosis (penicilliosis) marneffei among Human immunodeficiency VirusInfected patients in Malaysia. Med \& Health Dec. 2018;13(2):103-13.

2. Le T, Wolbers M, Chi NH, Quang VM, Chinh NT, Huonglan NP, et al. Epidemiology, seasonality, and predictors of outcomeof AIDS-associated Penicillium marneffei infection in Ho Chi Minh City, Vietnam. Clin Infect Dis. 2011;52(7):945-52.

3. Kok I, Veenstra J, Rietra P, Dirks-Go S, Blaauwgeers J, Weigel $H$. Disseminated Penicillium marneffei infection as an imported disease in HIV-1 infected patients: Description of two cases and a review of the literature. Neth $\mathrm{J}$ Med. 1994;44(1):18-22.

4. Liyan $X$, Changming L, Xianyi Z, Luxia W, Suisheng $X$. Fifteen cases of penicilliosis in Guangdong, China. Mycopathologia. 2004; 158: 151-5.

5. Surja SS, Adawiyah R, Wahyuningsih $\mathrm{R}$. Talaromikosis marneffei. Jurnal IImu Kedokteran. 2018;12(2):72-81.

6. Clinical Info HIV.Gov. Guidelines for the prevention and treatment of opportunistic infections in adults and adolescents with HIV. 2019 (diakses Agustus 2020). Tersedia dari: https://clinicalinfo.hiv.gov/ en/guidelines/adult-and-adolescent-opportunisticinfection/whats-new-guidelines

7. Wong SY, Wong KF. Penicillium marneffei infection in AIDS. Patholog Res Int. 2011;1-10.

8. Chariyalertsak S, Vanittanakom $\mathrm{P}$, Nelson KE, Sirisanthana T, Vanittanakom N. Rhizomys sumatrensis and Cannomys badius, new natutal animal hosts of Penicillium marneffei. J Med Vet Mycol. 1996;34:105 -10.

9. Kauffman CA. Central nervous system infection with other endemic mycoses: Rare manifestation of blastomycosis, paracoccidioidomycosis, talaro mycosis and sporotrichosis. Journal of Fungi. 2019; 5(64):1-15

10. Vanitha HD, Koorse KG, Sangeetha HD. Talaromycosis (Penicilliosis): A formidable challenge in Southeast Asia. International Journal of Medicine Research. 2018; 3(1):41-4.

11. Chan JFW, Lau SKP, Yuen K, Woo PCY. Talaromyces (Penicillium) marneffei infectio in nonHIV-infected patients. Emerg Microbes Infect. 2016;5(3):19.

12. Stone A, Park BJ. Penicillium marneffei infection: knowledge, gaps, and future directions. Curr Fungal Infect Rep. 2011;5:193-8.

13. Li HR, Cai SX, Chen YS, Yu ME, Xu NL, Xie BS, et al. Comparison of Talaromyces marneffei infection in human immunodeficiency virus-positive and human immunodeficiency virus-negative patients from Fujian, China. Chin Med J. 2016; 129 (9): 1059-65.

14. Kawila R, Chaiwarith $R$, Supparatpinyo K. Clinical and laboratory characteristics of Penicilliosis marneffei among patinets with and without HIV infection in Northen Thailand: a retrospective study. BMC Infect Dis. 2013;13:464.

15. Le T, Wolbers M, Chi NH, Quang VM, Chinh NT, Huonglan NP, et al. Epidemiology, seasonality, and predictors of outcome of AIDS-associated Penicillium marneffei infection in Ho Chi Minh city, Vietnam. Clin Infect Dis. 2011;52(7):945-52.

16. Cooper CR, Vanittanakom N. Insight into the pathogenicity of Penicillium marneffei. Futur Microbiol. 2008;3(1):43-55.

17. Huang $Y T$, Hung $C C$, Liao $H$, Sun $Y$, Chang $C$, Chen $\mathrm{CY}$. Detection of circulating galatomannanin serum samples for diagnosis of Penicillium marneffei infection and cryptococcis among patients infected with human immunodeficiency virus. Journal of Clinical Microbiology. 2007; 45 (9): 2858-62.

18. Boon-Long J, Mekha N, Poonwan N, Kusum M, Mikami Y, Yazawa $\mathrm{K}$, et al. In vitro antifunga activity of the new triazole D0 870 against Penicillium marneffei compared with that of amphotericin B, fluconazole, miconazole and flucytosine. Mycoses. 1996; 39(11):453-6. 